\title{
The Ethics of Gene Doping: A Survey of Elite Athletes and Academic Professionals
}

\author{
Kris Dierickx ${ }^{1 *}$, Seppe Deckx ${ }^{2}$ and Kristien Hens ${ }^{1}$
}

${ }^{1}$ Centre for Biomedical Ethics and Law, Kapucijnenvoer 35/3 Box 7001, 3000 Leuven, Belgium

${ }^{2}$ Afdeling Adapted Physical Activity en Psychomotorische Revalidatie, Tervuursevest 101 Box 1500, 3001 Heverlee, Belgium

\begin{abstract}
With the advent of genome-wide association studies more is known about genes that influence performance and health-related fitness. Gene therapy has the potential to be abused for performance gain by athletes. This is called gene doping. At the moment there is little known about the opinions of athletes and professionals with regard to the use of gene doping for performance gain. Therefore we found it useful to query the opinions of elite athletes at the Catholic University of Louvain and the professors working at the Faculty of Kinesiology and Rehabilitation Sciences. We received 75 questionnaires, corresponding to a response rate of $56 \%$. We used SAS Enterprise Guide 4 for the statistical analysis. We performed a frequency analysis and the data were tested using a bilateral Wilcoxon-MannWhitney $U$ test at a significance level of 0.05 to check for differences. We found that a majority of the respondents had already heard of gene doping. Also, people believed it to be a health risk. People thought that pressure from the environment was an important reason why athletes might use gene doping. Gene doping was also considered a threat to fair play.
\end{abstract}

\section{Keywords: Ethics; Gene doping; Doping; Survey}

\section{Introduction}

With the advent of genome-wide association studies more is known about genes that influence performance and health-related fitness [1]. Mouse models are generated with outstanding physical performance, by manipulating certain genes [2]. As genes have been identified that affect skeletal muscle size, metabolism and contractile properties, gene therapy has the potential to be abused for performance gain by athletes [3]. Such abuse is called gene doping [4,5]. The official definition by the World Anti-Doping Agency (WADA): 2011 Prohibited List is [6]:

The following, with the potential to enhance sport performance, are prohibited:

1. The transfer of nucleic acids or nucleic acid sequences;

2. The use of normal or genetically modified cells;

3. The use of agents that directly or indirectly affect functions known to influence performance by altering gene expression. For example, Peroxisome Proliferator Activated Receptor $\delta$ (PPAR $\delta$ ) agonists (e.g. GW 1516) and PPAR $\delta$-AMP-activated Protein Kinase (AMPK) axis agonists (e.g. AICAR) are prohibited.

The fundamental difference between gene therapy and gene doping is that the latter is not used to replace an absent or dysfunctional protein in an unhealthy individual but to artificially alter gene expression in a healthy individual [5]. Right now, there are no known cases of gene doping being used by athletes, although some suspect that it already being used $[7,8]$. Gene therapy constructs are already in circulation on the black market $[9,10]$. Although science progresses, and methods are being developed to detect gene doping [4], detection is still difficult. It is nearly impossible to differentiate between two proteins having the same function and structure, and produced in the same place by the same cellular machinery [2].

The question whether gene doping should be allowed is still ongoing. Some arguments are analogous to those quoted in the context of other types of doping, whereas others arise from the specific nature of gene doping. Basically, the themes in the arguments pro and contra doping are the health risks associated with the use of doping, the pressure on other athletes to use doping, the fact that athletes are role models for young people, the desirability of dope tests and the issue of fair play.

One of the most often quoted arguments in favor of a ban on gene doping is the fact that it would entail severe health risks [11-13]. For example, mouse models have shown the negative side effects of using gene therapy to enhance the performance of athletes, ranging from hyperactivity, aggressiveness; changes in cardiac functioning to allergic reactions to the viral vector used to deliver the alteration $[5,13,14]$. Also, athletes may have little knowledge about the dangers [15] Choosing the route that allows gene doping would make a performance a function of expert manipulation [16,10]. Others, however, argue that there is not enough proof of this and that sports in itself may be more risky than doping $[17,18]$. Some would therefore argue to allow doping under medical supervision [17].

Another argument used is that if gene doping is allowed this would force athletes who do not want to use gene doping to use it anyway, because otherwise they would have a competitive disadvantage $[16,19]$. But some argue that this argument is exaggerated. Athletes can choose not to use dope and not be part of a select group of winners. After all, winning should be equivalent with the efforts and risks taken; and athletes using gene doping take more risks. Also those who choose not to use doping still have the opportunity to have a professional career in sports [20].

*Corresponding author: Kris Dierickx, Centre for Biomedical Ethics and Law, Kapucijnenvoer 35/3 Box, 7001, 3000 Leuven, Belgium, Tel: + 3216 336955; Fax: +32 16 336952; E-mail: kris.dierickx@med.kuleuven.be

Received September 01, 2011; Accepted July 26, 2012; Published July 30, 2012

Citation: Dierickx K, Deckx S, Hens K (2012) The Ethics of Gene Doping: A Survey of Elite Athletes and Academic Professionals. J Clinic Res Bioeth 3:136. doi:10.4172/2155-9627.1000136

Copyright: ( 2012 Dierickx K, et al. This is an open-access article distributed under the terms of the Creative Commons Attribution License, which permits unrestricted use, distribution, and reproduction in any medium, provided the original author and source are credited. 
A third argument is that athletes are role models. When athletes are allowed to break the rules regarding doping this would entice young people to use drugs and dope and disregard the rules of society as well $[21,19]$. However, without a prohibition of doping there are no rules to transgress. Hence this argument cannot be used to forbid dope [22]. Moreover, the fact that athletes are role models is exaggerated [23]. Also, parents who regularly use alcohol or smoke have far more influence on young children, and this is not forbidden [20].

Last but not least, there are arguments pro and contra dope tests. Most athletes do not object to dope tests in general [24]. However, such tests may be seen as an invasion of privacy. Such invasion is only allowed to prevent others from serious harm. However, at the moment there is no real proof of serious harm, so dope tests cannot be justified [25]. In the context of gene doping, it is stated that dope tests can be invasive, such as muscle biopsies and thus are not enforceable [26]. Moreover, tests for gene doping may reveal unrelated and unsought for genetic information [26]. Genetic information is sensitive in the sense that it can be used by insurers to discriminate against the subject. Also, as genes are shared with family members, testing for gene doping could reveal information that is relevant for family members or future offspring as well.

There is little known about the opinion of professionals with regard to gene doping. Therefore we found it useful to query these opinions amongst top athletes and academic personnel at the Catholic University of Leuven. The remainder of this paper reports and discusses this survey.

\section{Methods}

The survey was sent to 81 students at the Catholic University Leuven who had the status of elite athlete during the academic year 2006-2007. In order to have the official status of elite athlete, a student has to belong to at least one of the following categories: $\mathrm{He}$ or she has to be an official athlete at the BOIC (Belgian Olympic and Interfederal Committee), or be selected for a national team (juniors or seniors) or in the individual sports be acknowledged by the national coach as a promising athlete or in the team sports be a member of a team in the highest division. The survey was also sent to all the professors $(n=52)$ working at the Faculty of Kinesiology and Rehabilitation Sciences (including Sport Sciences). We sent out a questionnaire composed of 31 questions (for the professors) or 33 questions (for the elite athletes) via email to these two groups, with a short letter explaining gene doping and guaranteeing confidentiality. The definition of gene doping presented to participants was 'Gene doping is the use of cells, genes or genetic elements with as an aim the improvement of performance. In other words, it is the use of genetics and gene therapy to be able to enhance athletic performance'. Reminders were sent after one and two weeks. At the latter point they were given the option to return the questionnaire anonymously by mail. The questionnaire was developed specifically for this investigation. The questionnaire is based on themes that arose from a literature review and was reviewed by a panel of experts in the field of biology, law, social sciences and ethics. This panel also contained one student and one professor of the Faculty of Kinesiology and Rehabilitation Sciences. The questions were subdivided in administrative questions (two for the professors and three for the students), a question regarding the attitude towards doping in general, a question regarding the experience with doping (only for the students), a question whether the respondent had already heard of gene doping, a question querying whether the respondent thought that gene doping was already used by athletes and questions querying the attitudes regarding gene doping.
We received 75 questionnaires, 23 from professors and 52 from students. Hence we achieved a response rate of $56 \%$, which is acceptable [27]. In similar studies querying the attitudes towards more traditional types of doping diverging return rates were found: $93 \%$ and $95 \%$ in surveys querying use of and the attitudes towards anabolic steroids of Swedish adolescents [28,29], $90 \%$ in a study querying the attitudes of Finnish athletes towards doping [30], 74\% in a study querying the perceptions of the effects of anabolic steroids amongst American students [31] and $60 \%$ in a survey querying the attitudes towards doping amongst French high school athletes.

To score the answers with regard to attitudes towards gene doping, we used a five-point Likert scale, where respondents could choose between 'completely disagree, rather disagree, no opinion, rather agree and completely agree'. We transformed the answers to a threepoint scale for statistical analysis. Because we measured the answers to the questionnaires on an ordinal scale, non-parametric statistics were used. We used SAS Enterprise Guide 4 for the statistical analysis. We performed a frequency analysis and the data were tested using a bilateral Wilcoxon-Mann-Whitney $U$ test at a significance level of 0.05 to check for differences. The original questionnaire was in Dutch. The questions were translated for publication purposes (Table 1).

\section{Results}

$77 \%$ agreed to the statement that 'I had already heard of gene doping before receiving this questionnaire'. This percentage was somewhat higher amongst professors than amongst students (87\% versus $73 \%$ ) but this difference was not significant.

We made a subdivision in the group of students between students that practised an individual sport (62\%) and students practising a team sport (38\%). There was a significant difference between individual athletes and team sport athletes with regard to the familiarity with gene doping $(\mathrm{z}=-2,9251 ; \mathrm{p}=0.0034) .88 \%$ of the individual athletes had already heard of gene doping whereas only $50 \%$ of the team sport athletes had heard of it. We also queried amongst the students whether they were already offered doping. $4 \%$ stated that they were already offered doping, whereas $96 \%$ were never offered doping.

Most respondents do not agree with the statement that 'Given good coaching, gene doping can be medically sound for athletes' (60\%). Here there is a significant difference between the professors and the students ( $78 \%$ that disagrees versus 52 that disagrees, $\mathrm{z}=-2,2577 ; \mathrm{p}=0.0240$ ). For the statement that 'the selection of young children based on their genetic disposition for sporting achievement can be defended in the policy of top sport' we find within the group of professors a significant difference between men and women $(z=2,1003$; $p=0.0357)$ : women agree more often with this statement than men.

Students unanimously disagree with two statements. First that 'Because of individual differences it is fair to allow gene doping amongst elite athletes and secondly that 'Because of differences in training facilities it is fair to allow gene doping amongst elite athletes'. Amongst the professors respectively $86 \%$ and 96 disagrees with this stance. For the first of these statements, the difference between students and professors is significant $(\mathrm{z}=2,6566 ; \mathrm{p}=0.0079)$.

\section{Discussion}

We have found that $73 \%$ of the students had already heard of gene doping. In a similar online questionnaire of 115 American young athletes this was only $39 \%$ [32]. In our study there was a significant difference between individual athletes and those part of a team $(\mathrm{z}=$ 


\begin{tabular}{|c|c|c|c|}
\hline & disagree & No opinion & agree \\
\hline I am in favour of a complete ban on doping for athletes & $5 \%$ & $0 \%$ & $95 \%$ \\
\hline I had already heard of gene doping before receiving this questionnaire & $23 \%$ & $0 \%$ & $77 \%$ \\
\hline I believe gene doping is already in use amongst elite athletes & $21 \%$ & $29 \%$ & $50 \%$ \\
\hline Gene doping is a health risk for athletes & $17 \%$ & $35 \%$ & $48 \%$ \\
\hline Given good coaching, gene doping can be medically sound for elite athletes & $60 \%$ & $16 \%$ & $24 \%$ \\
\hline Doing top sport in itself entails more risks than medically assisted use of gene doping & $53 \%$ & $25 \%$ & $22 \%$ \\
\hline Pressure from the environment is an important reason why elite athletes would use gene doping & $25 \%$ & $4 \%$ & $71 \%$ \\
\hline Career opportunities are an important reason for elite athletes to use gene doping & $11 \%$ & $3 \%$ & $87 \%$ \\
\hline Elite athletes are role models for other athletes with regard to the use of gene doping & $17 \%$ & $7 \%$ & $76 \%$ \\
\hline The use of gene doping amongst elite athletes inspires young people to transgress rules of society & $36 \%$ & $12 \%$ & $52 \%$ \\
\hline Genetic research as part of a dope test is an extreme breach of the privacy of an elite athlete & $83 \%$ & $4 \%$ & $13 \%$ \\
\hline $\begin{array}{l}\text { The selection of young children based on their genetic disposition for sporting achievement can be defended in the policy of top } \\
\text { sport }\end{array}$ & $58 \%$ & $10 \%$ & $32 \%$ \\
\hline The use of gene doping reduces the sportive merit of an elite athlete & $6 \%$ & $5 \%$ & $89 \%$ \\
\hline The genetic manipulation of unborn children for sporting achievements can be defended & $95 \%$ & $3 \%$ & $2 \%$ \\
\hline Gene doping is a threat to fair play in sports & $3 \%$ & $4 \%$ & $93 \%$ \\
\hline Because of individual differences it is fair to allow gene doping amongst elite athletes & $96 \%$ & $1 \%$ & $3 \%$ \\
\hline Because of differences in training facilities it is fair to allow gene doping amongst elite athletes & $99 \%$ & $0 \%$ & $1 \%$ \\
\hline Gene doping will radically change the character of top sport & $12 \%$ & $13 \%$ & $75 \%$ \\
\hline By using gene doping elite athletes suggest that money and fame are more important than effort and dedication & $18 \%$ & $11 \%$ & $71 \%$ \\
\hline Top sport is about the 'altius, citius, fortius' principle (higher, faster, stronger) and gene doping is part of that & $84 \%$ & $8 \%$ & $8 \%$ \\
\hline By allowing gene doping we shall be measuring technological achievements rather than human achievements & $5 \%$ & $11 \%$ & $84 \%$ \\
\hline Every human being has the right to be born with unaltered genes & $1 \%$ & $8 \%$ & $91 \%$ \\
\hline A society can prohibit something (hence also gene doping) by means of laws and rules. & $2 \%$ & $1 \%$ & $97 \%$ \\
\hline A elite athlete can be forbidden to use gene doping because this encourages others to also use it & $5 \%$ & $7 \%$ & $88 \%$ \\
\hline A elite athlete can be forbidden to use gene doping because this harms his or her own health & $11 \%$ & $28 \%$ & $61 \%$ \\
\hline $\begin{array}{l}\text { Elite athletes should be allowed to choose freely for gene doping, regardless of any restricting measure taken by sports } \\
\text { authorities }\end{array}$ & $92 \%$ & $5 \%$ & $3 \%$ \\
\hline $\begin{array}{l}\text { Each way of genetic intervention with unborn and under aged children should be forbidden because they should be allowed to } \\
\text { choose for this as competent adults }\end{array}$ & $18 \%$ & $12 \%$ & $70 \%$ \\
\hline $\begin{array}{l}\text { A genetic intervention to recover more quickly from an injury is therapeutic and hence the prohibition of gene doping does not } \\
\text { apply }\end{array}$ & $36 \%$ & $32 \%$ & $32 \%$ \\
\hline $\begin{array}{l}\text { Gene doping is in essence the same as other means of enhancement such as high altitude training or heavy training } \\
\text { programmes }\end{array}$ & $92 \%$ & $4 \%$ & $4 \%$ \\
\hline
\end{tabular}

Table 1: Frequencies for the attitudes towards gene doping $(n=75)$

$-2,951 ; \mathrm{p}=0.0034) .88 \%$ of the individual athletes had already heard of gene doping, whereas this was only the case for $50 \%$ of the athletes doing team sports. A first explanation could be that we only had a small number of respondents (32 individual athletes and 20 team sport athletes) and that a small number of people can already make a large difference in percentage. Another explanation could be that individual athletes are more concerned with their own performance and therefore more interested in information about performance gain. There may also be a correlation with the fact that the four percent athletes that stated they had already been offered dope were all individual athletes. A possible explanation can be found in the study by Alaranta et al. [30], who found that athletes in different sports also have a different attitude towards dope. Maybe this attitude is related to the fact whether they had already been offered dope. In that study the authors found that of the speed and power athletes $21 \%$ had been offered dope, whereas for the team sport athletes this was only $13.8 \%$, which would lead to the fact that individual athletes have more information about doping in general and as a consequence about gene doping in particular. However, this assumption is contradicted by findings in Polish athletes, that could not find a difference in attitudes between team sport athletes and individual athletes [33]. Moreover, a study by Ford found that in specific team sports substance abuse was more prevalent because these athletes are more influenced by friends and social norms [34].

We found that $48 \%$ of the respondents thought that gene doping contains a health risk. An American internet survey querying the opinions of college athletes from Oregon [32] found that $68 \%$ of the respondents thought there are health risks. In a similar study querying the health risks of doping in general, Alaranta et al. found that $74 \%$ though that it was a risk [30]. In a survey of high school athletes Laure et al. found that $93 \%$ thought that doping was always a health risk [35]. The seven percent that disagreed contained more boys than girls. We found no such differences in our research. A possible explanation why in our research less respondents believed the practice to be risky might be that gene doping is still relatively unknown, a hypothesis supported by the fact that $35 \%$ had no opinion on the matter. A reason why many would consider gene doping a health risk is that the science regarding genetic modification is still young and the risks, if any, are still unknowns. Reasons why people may think the use of gene doping is not risky is that there is not much scientific proof, or that some may believe that gene doping increases safety because top sport without doping is considered unhealthy.

Most respondents $(60 \%)$ do not agree with the stance that 'Given good coaching, gene doping can be medically sound for elite athletes'. $24 \%$ agreed to this. In the survey by Laure, $27 \%$ of the high school athletes questioned thought that doping products could be used without health risks under supervision of a doctor [35]. In a questionnaire surveying the opinions of coaches, $10.3 \%$ thought that doping products could be used without health risks [36]. In the study 
amongst school athletes, Laure found that boys agreed more with this stance than girls, a difference we did not find in our research. We did however find a difference between professors and students: amongst the professors, $78 \%$ did not agree with this stance, whereas this number was much lower amongst the elite athletes (52\%). We are not sure how to explain this difference. It may be that the professors in this specialty are more aware of the dangers related to gene doping.

$71 \%$ of our respondents thought that pressure from the environment is an important reason why elite athletes would use gene doping. This is acknowledged by a Dutch survey amongst elite athletes where $4 \%$ effectively felt this pressure [37]. In a study amongst Italian athletes, $62 \%$ of the athletes that used doping mentioned pressure from coaches or managers as a reason [38].

A majority of the respondents (83\%) disagrees with the statement that genetic research as part of a dope test is an extreme breach of the privacy of an elite athlete. This may be explained by the fact that many athletes think that dope tests are just part of the game or that one agrees to take such test because in that way one is sure that others are also tested. However this thought does not correspond with what the media report. Here, often the testing policy with regard to doping is questioned because of the lack of privacy that is the results of the checkups. We could not find an explanation why our respondents think differently. It is possible that the reports in the media are exaggerated and only focus on the opinion of a few people.

An often quoted issue with regard to doping in general and gene doping in particular is the question about the difference between therapy and enhancement: what is allowed and what should be forbidden? Our respondents had different opinions about the statement 'A genetic intervention to recover more quickly from an injury is therapeutic and hence the prohibition of gene doping does not apply' (36\% disagreed, $32 \%$ had no opinion and $31 \%$ agreed). This is indeed a difficult distinction, as questions related to therapy versus enhancement are difficult to answer. Mottram states in this respect that doctors are being condemned whether they do something or not [39].

With regard to fair play, 93\% thought that gene doping formed a serious threat. Students rejected the statement that 'Because of differences in training facilities it is fair to allow gene doping amongst elite athletes' more than professors. Also with regard to two other statements concerning fair play students answered more in favour of fair play. It is difficult to find an explanation for this. Is fair play more important for students than for professors? In a study amongst French high school students $94 \%$ of the respondents thought that the use of doping was equivalent to cheating [35]. Also in the internet questionnaire from Oregon $79 \%$ of the respondents thought that gene doping was a kind of cheating [32]. Explanations why gene doping is considered a threat to fair play may be related to the argument that it raises the chance to success in an unacceptable manner or because it means breaking a rule. In the study by Laure, the six percent that did not thought the use of dope was cheating, there was an obvious difference between boys and girls (9\% and 3\%) and between individual athletes and team sport athletes (5\% and 8\%) [35]. We do not find similar differences in our survey.

Our study has certain limitations. First, it was based on the answers from 75 respondents, which means that the opinion of some may have a proportionally big effect on the results. Secondly, we are dealing with a sensitive subject, which means that respondents may have given a socially acceptable answer, in order not to discredit themselves or their group. Thirdly it is possible that those who hold the most controversial opinions have not contributed as they might not wish to share these opinions.

Given the lack of similar studies with regard to doping and gene doping, we can state that there is a need for further research in a larger group. This is a similar conclusion as reached by the World Anti Doping Agency that states that there is a need for sociological, behavioural and ethical research to query the attitudes of athletes to the use of doping in sports $[30,35,40]$. Specifically with regard to the topic of gene doping we believe this study is an important starting point.

\section{Conflict of Interest}

The authors declare no conflict of interest

\section{References}

1. Trent RJ, Yu B (2009) The future of genetic research in exercise science and sports medicine. Med Sport Sci 54: 187-195.

2. Azzazy HM, Mansour MM, Christenson RH (2009) Gene doping: of mice and men. Clin Biochem 42: 435-441.

3. Harridge SD, Velloso CP (2008) Gene doping. Essays Biochem 44: 125-138.

4. Beiter T, Zimmermann M, Fragasso A, Armeanu S, Lauer UM, et al. (2008) Establishing a novel single-copy primer-internal intron-spanning PCR (spiPCR) procedure for the direct detection of gene doping. Exerc Immunol Rev 14: 7385.

5. McKanna TA, Toriello HV (2010) Gene doping: the hype and the harm. Pediat Clin North Am 57: 719-727.

6. World Anti-Doping Agency (WADA) (2011) The 2011 Prohibited List. International Standard

7. Pincock S (2005) Feature: Gene doping. Lancet 366: S18-S19.

8. Stouwdam $\mathrm{H}$ (2006) Turijn vreest eerste geval gendoping.

9. Gatzidou E, Gatzidou G, Theocharis SE (2009) Genetically transformed world records: a reality or in the sphere of fantasy? Med Sci Monit 15: RA41-RA47.

10. Friedmann T (2010) How close are we to gene doping? Hastings Cent Rep 40: $20-22$

11. Miah A (2001) Genetic technologies and sport: the new ethical issue. Philosoph Sport XXVIII: 32-52.

12. Haisma HJ, de HO (2006) Gene doping. Int J Sports Med 27: 257-266.

13. Coors ME, Hunter L (2005) Evaluation of genetic enhancement: will human wisdom properly acknowledge the value of evolution? Am J Bioeth 5: 21-22.

14. Trachtman $\mathrm{H}$ (2005) A man is a man is a man. Am J Bioeth 5: 31-33.

15. Friedmann T, Rabin O, Frankel MS (2010) Ethics. Gene doping and sport Science 327: 647-648.

16. Murray TH (2010) Making sense of fairness in sports. Hastings Cent Rep 40 $13-15$

17. Savulescu J, Foddy B, Clayton M (2004) Why we should allow performance enhancing drugs in sport. Br J Sports Med 38: 666-670.

18. Tamboer J, Steenbergen J (2000) Sportfilosofie. Leende: Damon

19. Olivier S (1996) Drugs in sport. Justifying paternalism on the grounds of harm. Am J Sports Med 24: S43-S45.

20. Tamburrini C (2000) What's wrong with doping? In: Tännsjö T, Tamburrini C (Eds), Values in sport: elitism, nationalism, gender equality and the scientific manufacture of winners. London: Spon 200-216.

21. Morgan WJ (2007) Ethics in Sport. (2nd edn), Human Kinetics, Champaign.

22. Schneider A, Butcher R (2000) A philosophical overview of the arguments on banning doping in sport. In: Tännsjö T, Tamburrini C (Eds), Values in sport: elitism, nationalism, gender equality and the scientific manufacture of winners, London: Spon 185-199.

23. Savulescu J (2006) Wordt topsport ooit zuiver?

24. Murray TH (2002) Reflections on the ethics of genetic enhancement. Genet Med 4: 27S-32S. 
Citation: Dierickx K, Deckx S, Hens K (2012) The Ethics of Gene Doping: A Survey of Elite Athletes and Academic Professionals. J Clinic Res Bioeth 3:136. doi:10.4172/2155-9627.1000136

Page 5 of 5

25. Schneider A, Butcher R (1994) Why Olympic athletes should avoid the use and seek the elimination of performance-enhancing substances and practices from the Olympic Games. Journal of the philosophy of sport, 20/21: 64-81.

26. Munthe $C$ (2005) Ethical aspects of controlling genetic doping. In: Tamburrini C, Tännsjö T (Eds), Genetic technology and sport: ethical questions. London: Routledge 107-125.

27. Portney L, Watkins M (2000) Foundations of clinical research: applications to practice.

28. Nilsson S, Spak F, Marklund B, Baigi A, Allebeck P (2005) Attitudes and behaviors with regards to androgenic anabolic steroids among male adolescents in a county of Sweden. Subst Use Misuse 40: 1-12.

29. Nilsson S, Baigi A, Marklund B, Fridlund B (2001) The prevalence of the use of androgenic anabolic steroids by adolescents in a county of Sweden. Eur J Public Health 11: 195-197.

30. Alaranta A, Alaranta H, Holmila J, Palmu P, Pietila K, et al. (2006) Self-reported attitudes of elite athletes towards doping: differences between type of sport. Int J Sports Med 27: 842-846.

31. Perko MA, Cowdery J, Wang MQ, Yesalis CS (1995) Associations between academic performance of division 1 college athletes and their perceptions of the effects of anabolic steroids. Percept Mot Skills 80: 284-286.
32. Geneforum (2005) Results from Oregon College Athlete Gene Doping.

33. Sas-Nowosielski K, Swiatkowska L (2008) Goal orientations and attitudes toward doping. Int J Sports Med 29: 607-612.

34. Ford JA (2007) Substance use among college athletes: a comparison based on sport/team affiliation. J Am Coll Health 55: 367-373.

35. Laure P, Lecerf T, Friser A, Binsinger C (2004) Drugs, recreational drug use and attitudes towards doping of high school athletes. Int J Sports Med 25: 133138.

36. Laure P, Thouvenin F, Lecerf T (2001) Attitudes of coaches towards doping. J Sports Med Phys Fitness 41: 132-136.

37. de Groot S, Hartgens F, Zweers M (1999) Enquete onder topsporters over doping, dopingcontroles en medicijn-gebruik in de sport.

38. Scarpino V, Arrigo A, Benzi G, Garattini S, La VC, et al. (1990) Evaluation of prevalence of among Italian athletes. Lancet 336: 1048-1050.

39. Mottram DR (2003) Evaluation of prevalence of "doping" among Italian athletes. London: Routledge 357-378.

40. Mottram DR (1999) Banned drugs in sport. Does the International Olympic Committee (IOC) list need updating? Sports Med 27: 1-10. 